\title{
不働態ステンレス鋼の耐食性に及ぼすエッチング 前処理電位と不働態化処理電位の影響*
}

\section{Effect of the Potential of Etching Treatment and Passivation Treatment on the Stability of Passive Stainless Steels}

\author{
Toshio Shibata† \& Go Okamoto††
}

\author{
$\dagger$ Metals Research Institute, Faculty of Engineering, \\ Hokkaido University (Nishi 8-chome, Kita 13-jo, \\ Sapporo-shi, Japan) \\ tt Faculty of Science, Science University of Tokyo \\ (1-3, Kagurazaka, Shinjuku-ku, Tokyo, Japan)
}

\begin{abstract}
Stability of the passive 18-8 steel in acid solution is found to depend on the potential during the etching treatment as well as the passivation treatment. The potential of the steel during the passivation treatment is controlled by changing the concentration of nitric acid solution or by using a potentiostat. Also a constant potential of the steel during the etching treatment is attained in a dilute nitric acid solution or in a concentrated sulphuric acid solution with or without applying the external polarization. Stability which is decided by measuring the self-activation time in oxygen-free sulphuric acid solution increases with increasing the potential of the passivation treatment, and a critical potential, at which the stability changes abruptly, is admitted irrespective of the method of the passivation treatment, i.e., chemical passivation or potentiostatically controlled passivation. Structural changes of the passive film are concluded to take place at this critical potential of $0.4 \mathrm{volt}$ (vs. SCE). Etching potential, also, changes the self-activation time of the passive steel treated at a constant passivation condition. The maximum stability is obtained at $-0.32 \mathrm{~V}$ of the etching potential. This fact is explained by assuming the selective enrichment of chromium on the surface bofore passivation.
\end{abstract}

\section{1 まえがき}

ステンレス鋼の耐食性が，表面の履歴，すなわち不働 態化する以前の前処理条件 ${ }^{1)}$ や不働態化処理条件 ${ }^{2)}$ によ ってさまざまに変化することはよく経験されるところで ある。われわれはすでに不働態皮膜の構造が皮膜形成電 位，すなわち不動態化処理電位によって変化し，これと ともに耐酸化性や酸中における耐食性が大きく変化する ことを報告 ${ }^{3,4)}$ した。

* 昭和 47 年 2 月 北海道腐食研究会（札幌）において発表

** 北海道大学工学部附属金属化学研究施設（札幌市北13条西 8 丁目)

*** 東京理科大学理学部 (東京都新宿区神楽坂 1 の 3 )
ところでステンレス鋼のような合金では, エッチング または活性化前処理によって, 表面への特定成分の濃縮 や，あるいは特定の腐食生成物の沈積が生ずると考えら れる。これらがその後に形成される不働態皮膜の性状を 支配するであろうことは容易に想像されるが，この点に ついての研究は少ない。

本研究においては, 硝酸による化学的不働態化, ある いはポテンショスタットを用いた定電位不働態化によっ て得られる不㗢態化オーステナイトステンレス鋼の耐食 性に対する, 不働態化処理 や前処理エッチングの影響 を, とくに電位に着目して調へ, 分極曲線との比較から 特定成分の濃縮の可能性を検討した。 


\section{2 実}

試料は SUS 27 のオーステナイトステンレス鋼であり その組成を Table 1 に示した。 $2 \mathrm{~mm}$ 厚さの板材から, Fig. 1 に示した形状の試片を切り出し，0/6 番のエメリ 一仕上げの後, 真空中で $1,100{ }^{\circ} \mathrm{C} \times 10$ 分の溶体化処理を 行ない,これを急冷した。ふたたび $0 / 6$ 番のエメリ一紙 で表面を研摩した後, 試片の柄部に直径 $1.8 \mathrm{~mm}$ のステ ンレス鋼線を点溶接し，これを導線をかねた支持棒とし た。

表面活性化のためのエッチング前処理，およびその後 の不働態化処理，ならびに不働態化した鋼の耐食性を判 定するための酸素を含まない濃硫酸中における自己活性 化時間の測定などの条件について，まとめて Table 2 に 示した。電位や温度などの影響を知るために，エッチン グ処理と不働態化処理の条件さいろいろと変えたが，そ れらの組合せを Table 2 にから $\mathrm{E}$ までに示してある。 たとえばAの実験では $0 / 6$ 番研摩仕上げした 鋼試片 を, $50{ }^{\circ} \mathrm{C}$ の $10 \% \mathrm{HNO}_{3}$ 中に浸漬し 10 分間保つ。その時 の鋼の試片浸漬中の電位は Fig. 2 に示したように, -0.1 $\mathrm{V}$ から $-0.045 \mathrm{~V}$ (vs. SCE) に変化する。この 10 分後 の最終電位を Table 2 に, エッチング電位, $E_{\text {etch.とし }}$ て $(-0.045 \mathrm{~V})$ のように示した。その後鋼試片を取り出 し，蒸留水で洗浄後，50 $\mathrm{C}$ の $10 \%$ から $60 \%$ までの種々 の濃度の硝酸溶液中に浸漬する。鋼試片の電位は, Fig. 2 に示したように時間とともに貴になるが 60 分後にはほ ぼ一定の值を示すょうになる。このときの 60 分後の浸漬 電位を, 不働態化処理電位, $E_{\text {p.t. }}$ として $(0.14 \sim 0.89 \mathrm{~V})$

Table 1. Composition of the steel.

\begin{tabular}{ccccccc}
\hline $\mathrm{Cr}$ & $\mathrm{Ni}$ & $\mathrm{C}$ & $\mathrm{Mn}$ & $\mathrm{P}$ & $\mathrm{S}$ & $\mathrm{Si}$ \\
\hline 19.19 & 8.09 & 0.07 & 1.20 & 0.034 & 0.008 & 0.55 \\
\hline
\end{tabular}

のように Table 2 中に示してある。Table 2 中で（）. をつけて示した電位值は，いずれも処理における最終的 に到達した自然浸漬電位を意味している。ポテンシオス

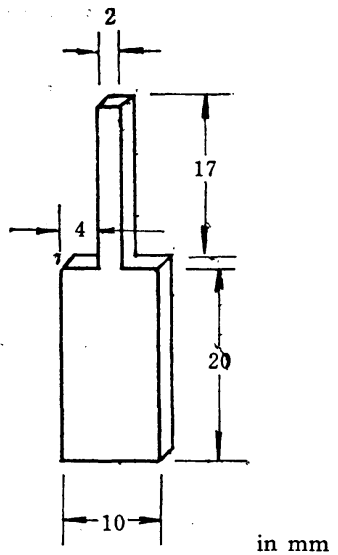

Fig. 1 Shape and dimensions of the specimen.

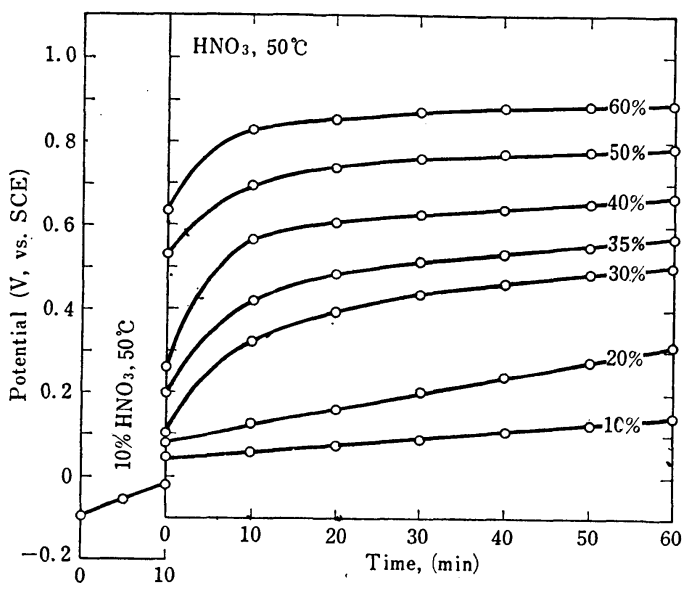

Fig. 2 Change of the potential during the treatment of etching and passivation.

Table 2. Various conditions examined for the etching treatment and the passivation treatment.

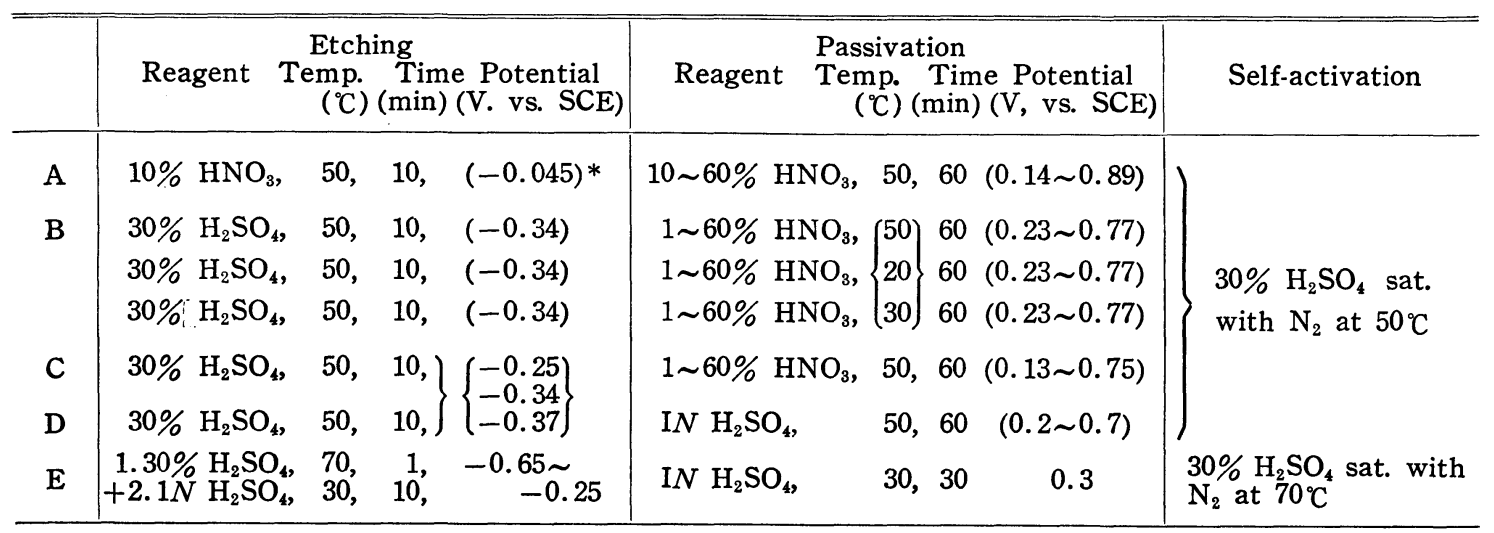

* Numerical value in the bracket indicates the natural potential attained at the end of the treatment. 


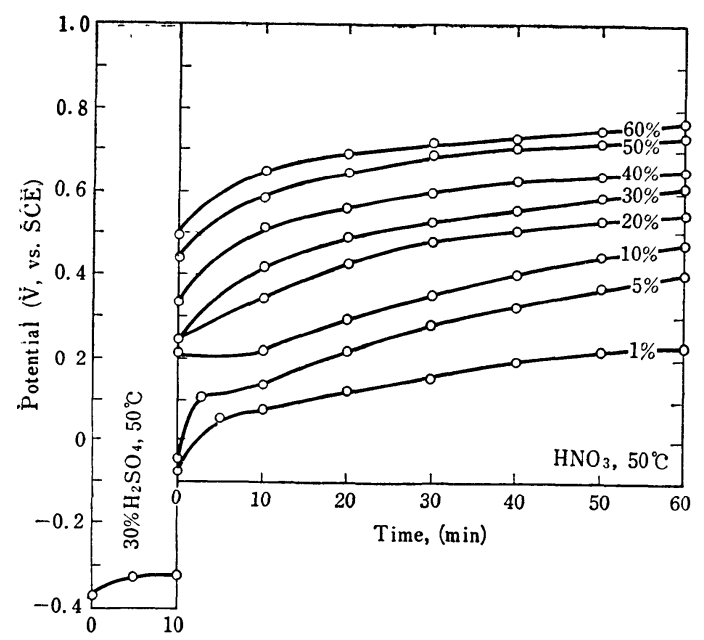

Fig. 3 Change of the potential during the treatment of etching and passivation.

タットによる定電位エッチング処理, あるいは定電位不 働態化処理の場合には, 電位の值は（）をつけずに示 してある。

不働態化処理を行なった試片を溶液から取り出し, 蒸 留水で洗浄後, $50^{\circ} \mathrm{C}$ の窒素飽和 $30 \%$ 硫酸中に移し, そ の電位変化を追跡した。そのときの活性化電位まで降下 し, 水素発生に至る時間を測定し, これを自己活性化時 間, $\tau_{\mathrm{a}}$,として不働態化ステンレス鋼の耐食性を判定し た。なお，この場合のみ溶存酸素を除去する目的で，精 製窒素ガスを $30 \%$ 硫酸溶液に飽和させ, 実験中も溶液上 に連続して窒素ガスを流した。これ以外のエッチング処 理，および不働態化処理においては，いずれも空気開放 下の溶液を用いた。なお自己活性化の実験はAからDま では $50^{\circ} \mathrm{C}$ で行なったが，Eのみは実験時間を短縮する 目的で $70^{\circ} \mathrm{C}$ で行なった。電位はいずれも飽和カロメル 電極に照合して測定し，そのままの值で示してある。

\section{3 実験 結 果}

\section{$3 \cdot 1$ 硝酸不動態化処理における浸暴電位}

Fig. 2 に, Table 2 に示したA 処理,および不働態化処理中における鋼電位の時間的変 化を示した。この場合エッチングは 10\% 硝酸で行なっ たが，浸漬中の電位は，図にみられるように $-0.1 \mathrm{~V}$ か ら $-0.034 \mathrm{~V}$ に変化する。この電位は, 分極曲線上では 不働態域にある。Fig. 3 はBの条件，すなわち $30 \%$ 硫 酸エッチングと硝酸不働態化を組合せた場合の変化であ る。エッチング電位は $-0.34 \mathrm{~V}$ でり, 完全な活性態電 位域にある。

不働態化処理中の電位は, Fig. 2 においても Fig. 3 に おいても時間とともに貴方向に変化し，また硝酸濃度が 高いほど貴の值をとる。Fig. 4 に硝酸濃度に対する，60

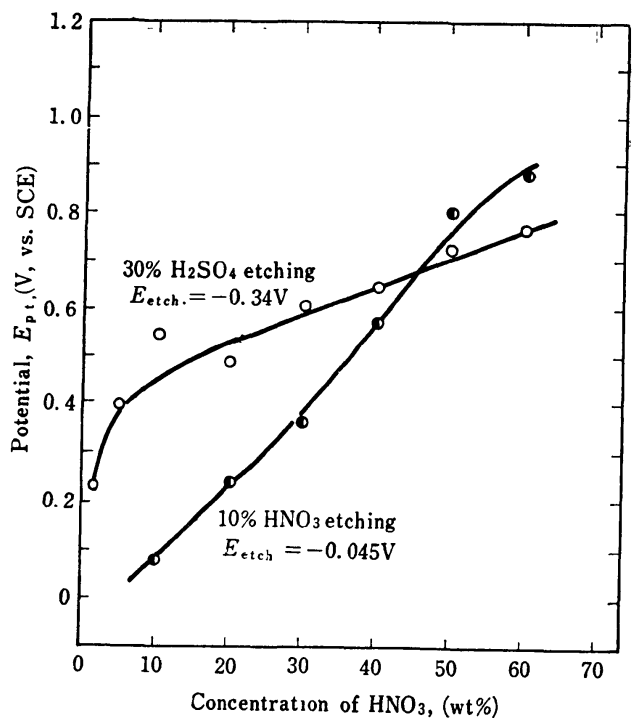

Fig. 4 The potential of the passivation treatment attained in the nitric acid solution of various concentration.

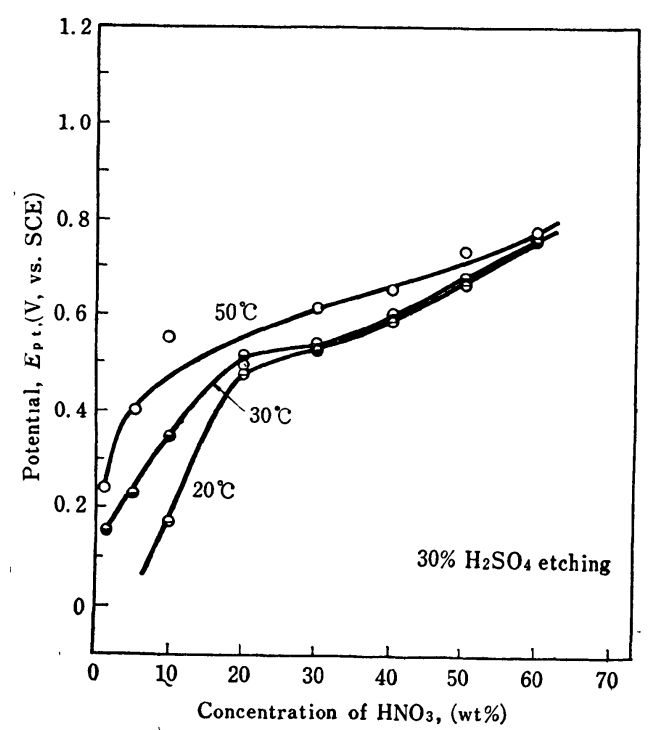

Fig. 5 Change of the potential of the passivation treatment with change of temperature of nitric acid solution.

分後の不働態化処理電位, $E_{\mathrm{p} . t .}$ を示した。図中の 2 本 の曲線は, $30 \%$ 硫酸エッチングの場合と, $10 \%$ 硝酸エッ チングの場合とを示しているが, 前者の曲線は後者に比 べて，低濃度域においてずっと貴の電位をとる。Fig. 3 と同様なBの条件で, 不働態化処理の温度のみを変化さ せた場合の結果を Fig. 5 に示した。図から明らかなよう に, 不働態化処理温度が高い場合には, 同濃度の硝酸を 用いても，鋼の最終電位は高くなることがわかる。とく

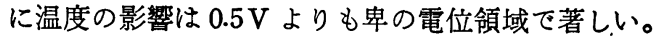




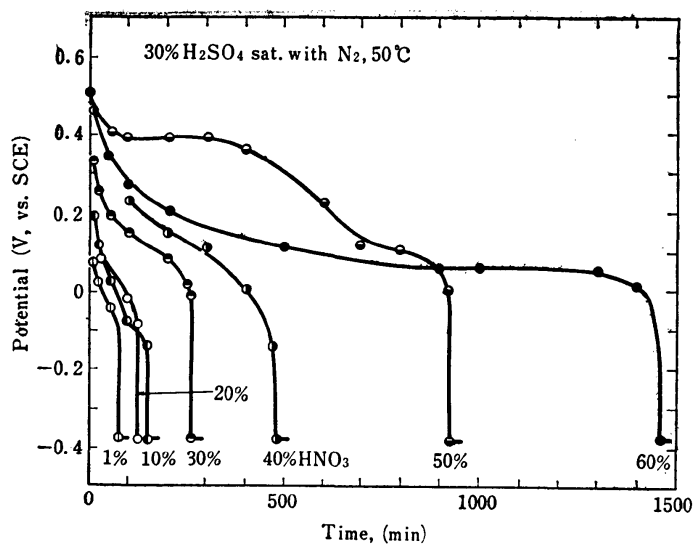

Fig. 6 Potential decay of passive steels during the self-activation process.

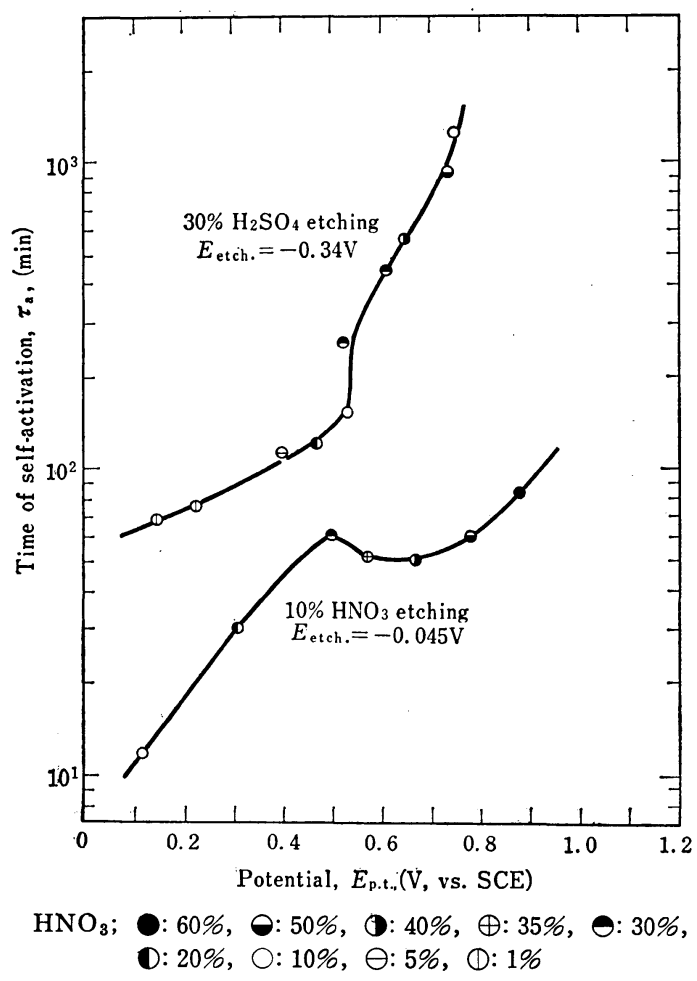

Fig. 7 Relation between the self-activation time and the potential of the passivation treatment in the nitric acid solution.

\section{$3 \cdot 2$ 自己活性化時間}

$\mathrm{B}$ の条件て処理した不働態化試片の $30 \%$ 硫酸， $50^{\circ} \mathrm{C}$, 中での自己活性化過程における電位の変化を Fig. 6 に示 した。鋼試片の電位は不働態域の電位から急速に早方向 へ変化し, $0 \mathrm{~V}$ 近傍に停滞した後, 再び急速に変化して $-0.38 \mathrm{~V}$ の活性態電位に達する。この電位において激し い水素発生が認められる。

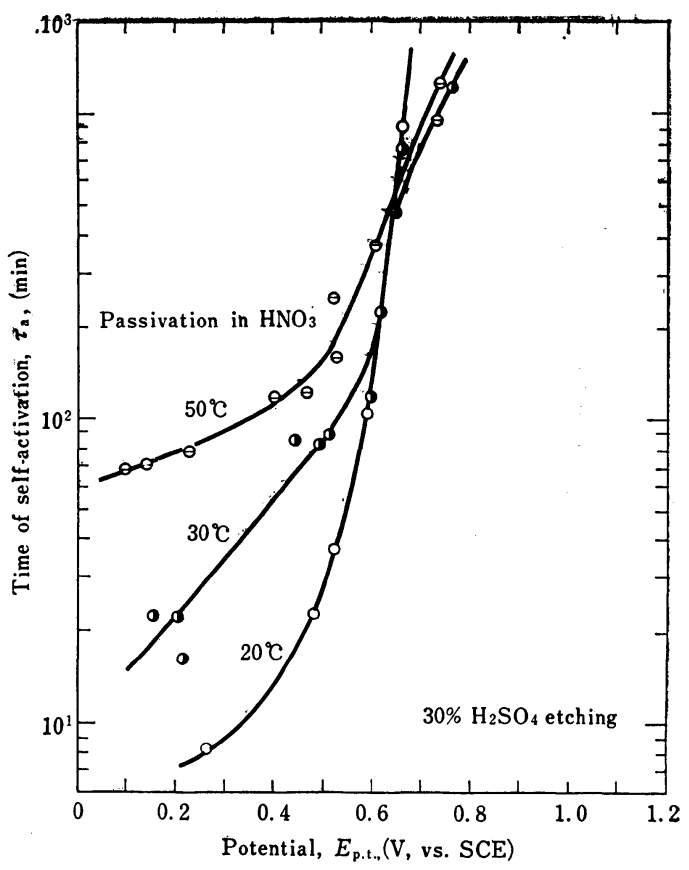

Fig. 8 Relation between the self-activation time and the potential of the passivation treatment in the nitric acid solution at $50^{\circ} \mathrm{C}, 30^{\circ} \mathrm{C}$ and $20^{\circ} \mathrm{C}$.

図からも明らかなように，高濃度の硝酸を用いて不働 態化した試片ほど活性化するまでの時間が長い。すでに 述べたように, 高濃度の硝酸を用いるほど不働態化処理 電位は貴の值をとるが，この值と自己活性化時間との関 係を示したのが Fig. 7 である。

すなわち高濃度の硝酸を用いると，鋼の不働態化処理 電位を貴にすることができるが，それとともに自己活性 化時間が長くなることがわかる。また Fig. 7 から明らか なように，同じ不働態化処理電位でも，エッチング方法 によって自己活性化時間は大きく変化する。すなわち 10 \% 硝酸エッチングの場合に比較して $30 \%$ 硫酸エッチン グの場合のほうが，自己活性化時間は一般に長くなって いる。また両者の場合とも，ほぼ $0.5 \mathrm{~V}$ を境としてそれ よりも貴の電位域で自己活性化時間が長くなる。

Fig. 8 はおなじ $30 \%$ 硫酸エッチングの場合について, 硝酸不働態化処理の温度を変化させたときの自己活性化 時間の不働態化処理温度依存性を示したものである。 Fig. 7 と同じく，いずれの処理温度においても $0.5 \mathrm{~V}$ 近 傍より貴の電位域で，自己活性化時間は大きくなってい る。そして処理温度の影響は低電位域で大きい。

\section{$3 \cdot 3$ 自己活性化時間に及ぼすエッチング電位の影篦}

Fig. 7 で示したように, 30\%硫酸エッチングでは $10 \%$ 硝酸エッチングよりも自己活性化時間は長いが，このと きのエッチング電位を調べてみると，眓中に示したよう 


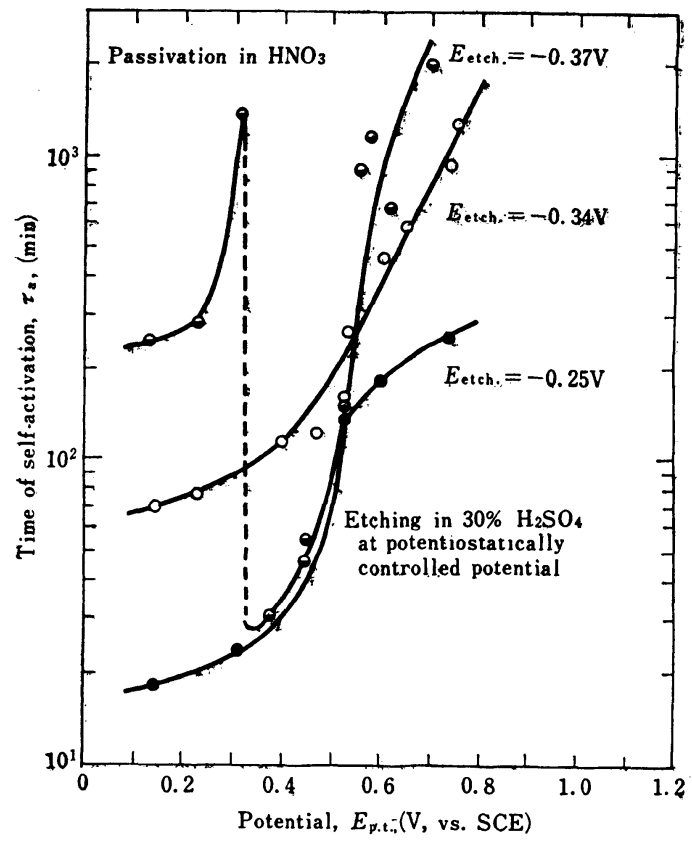

Fig. 9 Relation between the self-activation time and the potential of the passivation treatment in the nitric acid solution. The etching treatment is applied at a constant potential by using a potentiostat.

に $30 \%$ 硫酸 エッチングの場合は $E_{\mathrm{etch}}$.\#ー $0.34 \mathrm{~V}$ であ り，10\%硝酸エッチングの場合には $E_{\text {etch }}=-0.045 \mathrm{~V}$ て ある。すでに述べたように一-0.34V V完全な活性態電位 域にあり, 活発な水素発生を伴ってエッチングされる。 しかしこれに対して， $-0.045 \mathrm{~V}$ は不動態電位域にあり， この場合には，0/6研摩面はその光沢を保ったまま，少 し溶解するのが認められるのみである。このように不働 態化ステンレス鋼の自己活性化時間が，不働態化処理以 前のエッチング電位に依存することが明らかとなったの で，活性態域の三つの電位を選んて，自己活性化時間に 対するエッチング電位の影響を調へたた。結果をFig. 9 お よび Fig. 10 に示した。Fig. 9 は硝酸不働態化の場合で あり, Fig. 10 は $1 N$ 硫酸中で゚゚テンショスタットを用い て定電位的に不働態化した鋼についての結果である。 Table 2 の C, D に示したようにエッチングはいずれも $30 \%$ 硫酸中でポテンショスタットを用いて定電位に保つ ことによって行なった。

Fig. 9, Fig. 10 とも $E_{\text {p.t. }}+0.5 \mathrm{~V} よ り$ 早の不働態処 理電位において， $E_{\text {etch. }}=-0.34 \mathrm{~V}$ の場合に最も大きい 自己活性化時間を示している。なお Fig. 9 においては， $E_{\mathrm{p} . \mathrm{t} .}=0.3 \mathrm{~V}$ より卑の電位域に， $\tau_{\mathrm{a}}$ の異常な増加が認め られるがここの原因は明らかてない。

Fig. 11 は，とくに不㧝態化処理電位を一定とした場

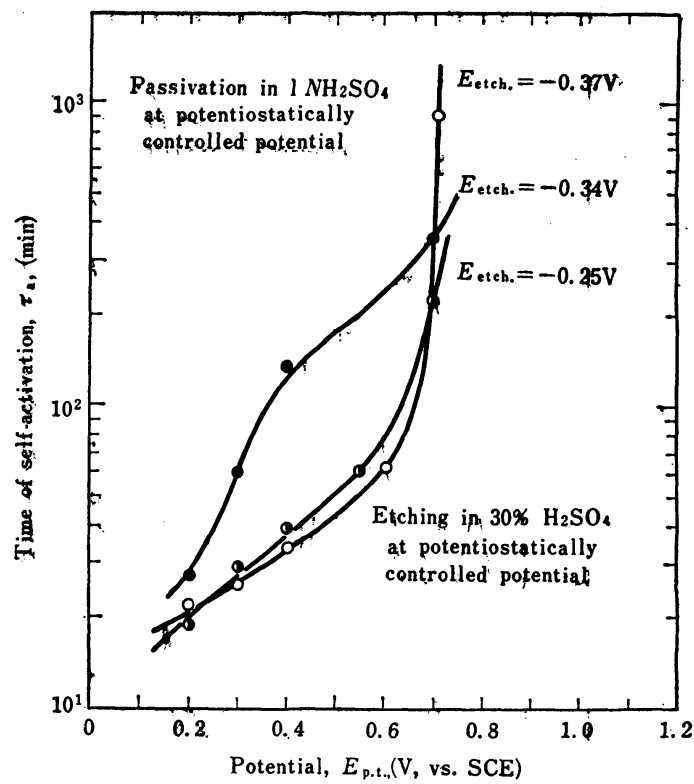

Fig. 10 Relation between the self-activation time and the potential of the passivation treatment. The potential during either the etching treatment or the passivation treat. ment is controlled by a potentiostat.

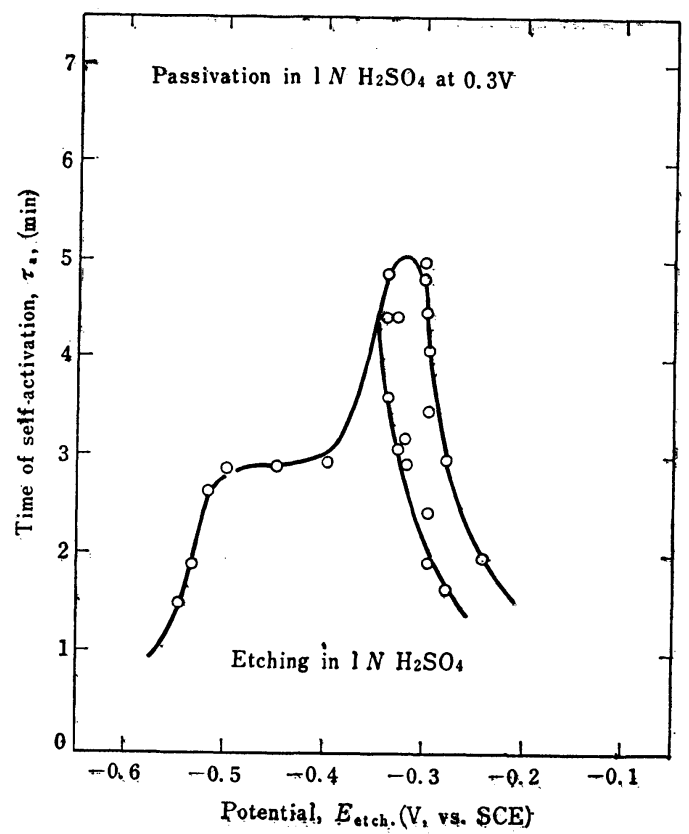

Fig. 11 Charge of the self-activation time against the etching potential applied by a potentiostat. After etching, all of the specimens are passivated at a constant condition of $+0.3 \mathrm{~V}$ for $30 \mathrm{~min}$.

合の自己活性化時間に対するエッチング電位の影帮を示 


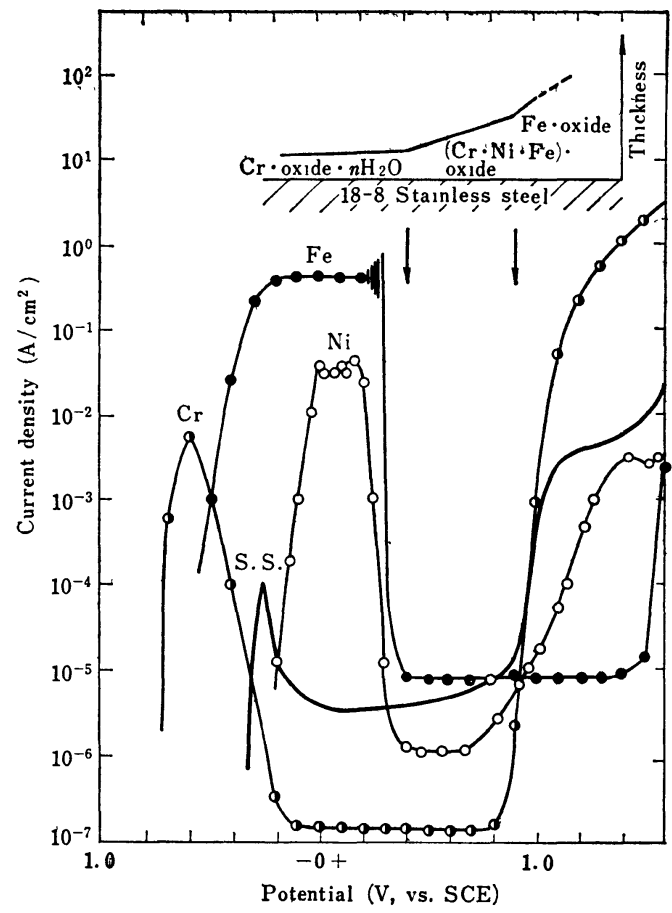

Fig. 12 Polarization curves for 18-8 stainless steel and its constituent metals, i. e., $\mathrm{Fe}, \mathrm{Ni}$ and $\mathrm{Cr}$. The schematic sketch indicated in the upper part of the figure is a model of the film formed in the corresponding potential region.

したものである。この場合実験時間を短くするために， 不働態処理時間を短くし，また自己活性化過程の温度を 高くした，Table 2 のの条件で実験を行なっている。 図より明らかなように, $E_{\text {etch. }}=-0.32 \mathrm{~V}$ 近傍に最大の $\tau_{\mathrm{a}}$ が認められ，それよりも貴の電位でも早の電位でも $\tau_{\mathrm{a}}$ は短くなる。また貴の電位では $\tau$ 住にきなバラッキが 認められる。

\section{4 考察}

\section{1 自己活性化時間と不働態化処理電位の関係}

Fig. 7〜10などから明らかなように，硝酸による不働 態化処理によっても，あるいはポテンシォスタットによ る定電位不働態化処理によっても，鋼の自己活性化時間 はエッチング電位が同一ならばそのときの不働態化処理 電位によって決定されている。すなわち鋼表面に生成す る不動態皮膜の耐食性が，その生成時の電位によって決 定されていることを示すものである。また $0.5 \mathrm{~V}$ 近傍を 境界として，それよりも貴の電位域で不働態化処理をす ると，不働態化鋼の自己活性化時間は著しく増大する。 著者らは皮膜の生長速度則を検討した際 ${ }^{5)}$ に, 速度則の 定数が $0.4 \mathrm{~V}$ を境として変化することを見いだしたが， 上に述へた耐食性の変化はこの速度則の定数の変化する
電位 $0.4 \mathrm{~V} よ り$ 始まっているものと考えられる。またす

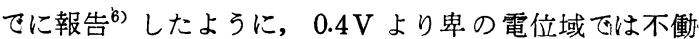
態皮膜中の結合水が, 貴の電位域に比べて多く,この結 合水が自己活性化過程での反応活性点となっていると考 えられる。すなわち比較的多い結合水に対応して自己活 性化時間が短くなっているのであろう。

Fig. 12 に $\mathrm{Cr}^{7)}, \mathrm{Ni}^{8)}, \mathrm{Fe}$ および 18-8 ステンレス鋼. の分極曲線を示した。 $\mathrm{Cr}$ は $-0.2 \mathrm{~V} よ り$ 不働態となり， $0.9 \mathrm{~V}$ より電流増加を示し過不働態溶解をする。ステン レス鋼の分極曲線もほぼ一致した挙動を示していること がわかる。すなわちステンレス鋼の分極曲線は Cr の分 極曲線を基本として，それに $\mathrm{Fe}$ と $\mathrm{Ni}$ の分極曲線を重 ねることによって得られると考えてよかろう。

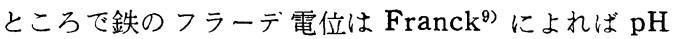
$=0.35$ て $0.32 \mathrm{~V}$ (vs. SCE) であり, Ni のそれは佐藤 ${ }^{8}$ ) によれば $0.22 \mathrm{~V}$ (vs. SCE) である。したがって Fig. 12 にみられるように $\mathrm{Fe}$ は約 $0.3 \mathrm{~V}$ 以下では大きな溶解電 流を示し, $\mathrm{Ni}$ は約 $0.2 \mathrm{~V}$ 以下で同様に大きな溶解電流を

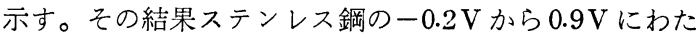
る広い不働態電位域のうちで, $\mathrm{Fe}$ と $\mathrm{Ni}$ のフラーデ電位 以下の電位領域では, $\mathrm{Fe}$ と $\mathrm{Ni}$ は溶解し $\mathrm{Cr}$ のみが不動 態を示すと考えられる。

このようにステンレス鋼と; その 3 種の構成元素の分 極曲線との比較から，ステンレス鋼の耐食性の変化する $0.4 \mathrm{~V}$ なる電位は，主として $\mathrm{Cr}$ によって生ずる不働態 電位域から, $\mathrm{Cr}, \mathrm{Ni}, \mathrm{Fe}$ の三者が共存して不働態を生 ずる電位域へ変化する臨界電位と考えるのが妥当であろ

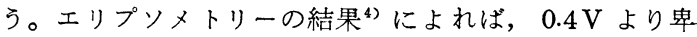
の電位域では皮膜厚さは比較的うすいが， $0.4 \mathrm{~V}$ より貴 の電位域で厚く，しかも皮膜厚さ増加の電位依存性孔 大である。 $\mathrm{Cr}$ の不働態皮膜はきわめてうすいことが知 られている(10)が，この事実も $0.4 \mathrm{~V}$ 以下の電位域の皮膜 が主として $\mathrm{Cr}$ 不働態皮膜からなることを示唆している ものと考えられる。

Fig. 12 の図中上部には，従来の結果执よび上の考察 から推定される不働態皮膜を示した。〜 $0.4 \mathrm{~V}$ まではう すいが，結合水を含む $\mathrm{Cr}$ 酸化物皮膜， $0.4 \mathrm{~V} \sim 0.9 \mathrm{~V}$ 厄 は比較的厚い $(\mathrm{Fe}, \mathrm{Ni}, \mathrm{Cr})$ 酸化物皮膜, $0.9 \mathrm{~V}$ 以上では $\mathrm{Cr}, \mathrm{Ni}$ の過不働態溶解が進行するので $\mathrm{Fe}$ 主体の皮膜と 推定している。なお， $\mathrm{Ni}$ の不働態皮膜がきわめてうす (11,12) ことや， $\mathrm{Fe}-\mathrm{Cr}-\mathrm{Ni}$ 合金上の不働態皮膜の厚さ や，その電位依存性あるいは届折率が純 Fe のそれとほ

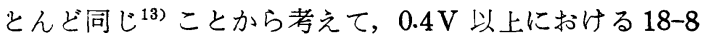
ステンレス鋼の不㗢態皮膜の主体は $\mathrm{Fe}$ 酸化物と考えて よいようである。

$4 \cdot 2$ 自己活性化時間に対するエッチング電位の影䈏 硝酸による不働態化処理の場合においても（Fig. 7, 
Fig.9), 定電位不働態化処理の場合においても(Fig. 10), $\tau_{\mathrm{a}}$ に及ぼすエッチング電位の影響は大きい。ステンレス 鋼中の各成分はエッチング処理中の電位に応じて，それ ぞれ異なった溶解速度をとるが，このような溶解速度の 相異は必然的に特定成分の選択的な濃縮をもたらすもの と考えられる。エッチング処理中に濃縮した特定成分が その後の不働態処理によって生成した皮膜の主成分とな

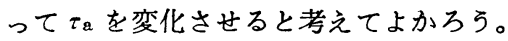

いま一定のエッチング電位について考えてみると, 溶 解電流の大きな成分は, 小さな成分に比して溶解しやす く，後者が表面に濃縮すると予想される。また成分間の 溶解速度の差が大きいほど, また処理時間が長いほど選 択的濃縮の可能性が大きくなる.と考えられる。

平衡電位值とは異なり, 速度パラメータについては純 金属についても明確に与えることはできないので，現在 のところ濃縮を定量的に論ずることはできない。しし ながら定常分極曲線を比較することによって，おおよそ の溶解と濃縮の傾向を知ることはできる。

Fig. 13 に活性態電位域に打ける $\mathrm{Fe}, \mathrm{Cr}, \mathrm{Ni}$ 扎よび 18-8ステンレス鋼の定常分極曲線と，Fig. 11 て得られ た $\tau_{\mathrm{a}}$ の值とを比較して示した。図から明らかなように， $\tau_{\mathrm{a}}$ の極大を示すエッチング 電位は $-0.32 \mathrm{~V}$ 近くであっ て,この電位においては $\mathrm{Cr}$ および $\mathrm{Ni}$ のアノード電流

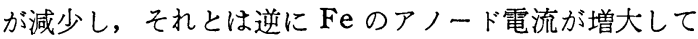
いる。つまりこのー0.32 V 近くの電位においてはステン レス鋼表面の $\mathrm{Fe}$ は選択的に溶解し， $\mathrm{Cr}$ と $\mathrm{Ni}$ が残留す る可能性が大きいと推定される。したがこてエッチング 後引き続いて不働態化処理をした場合，エッチング中に 濃縮された $\mathrm{Cr}$ と $\mathrm{Ni}$ が生成した不働態皮膜の主要成分 となっているものと考えられる。ただし＋0.3Vで不働 態化処理を行なっているので， Ni は不働態化処理中に 溶解してしまう可能性があり, 結局 $\mathrm{Cr}$ が皮膜主要成分 となっているであろう。このような $\mathrm{Cr}$ の濃縮の結果， 生成した不働態皮膜の耐食性が増大したものと考えられ る。

また図から明らかなように， Cr の溶解電流の極大值 が認められる電位までエッチング電位を卑にすると， $\tau_{\mathrm{a}}$ が減少するが,これは $-0.32 \mathrm{~V}$ の場合とは逆に $\mathrm{Cr}$ が選 択的に溶解し去ることによるとして説明できる。上に述 べた考察において各成分は合金化しても分極曲線の形状 には変化がないと仮定しているが，この仮定は最も荒い 近似であって実際は変化があると考えるべきであろう。

\section{5 結}

酸性溶液中における不働態化ステンレス鋼の耐食性 が，エッチング処理電位および不働態化処理電位によっ て決定されることを見いだした。

$10 \%$ 硝酸あるいは $30 \%$ 硫酸溶液を用いた化学エッチ

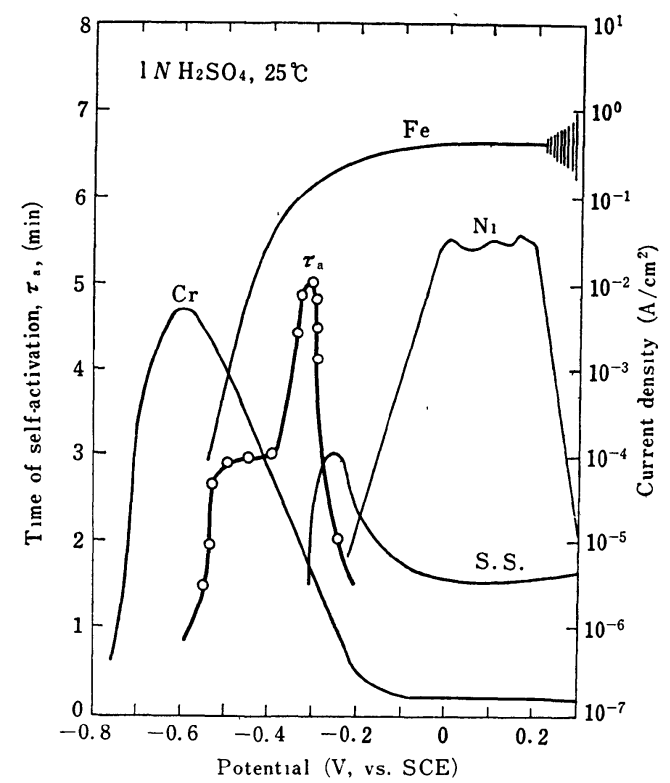

Fig. 13 Comparison between the polarization curves for 18-8 stainless steel and pure metals in the active potential region and the self-activation time of the passive steels, which are obtained at a constant passivation potential of $0.3 \mathrm{~V}$ after the etching treatment at various potentials indicated in the figure.

ングあるいは硫酸溶液中でポテンショスタットを用い て定電位エッチングによって表面を活性化処理した。不 働態化処理の場合も化学的および定電位的な方法を用い た。すなわち化学的不働態化処理においては種々の濃度 の硝酸中に鋼を浸漬して, 鋼電位を活性態電位域から不 働態電位域へ変えた。また硫酸中においてはポテンショ スタットによって定電位的に鋼電位を不働態電位域に設 定した。

酸素を取り除いた窒素飽和 $30 \%$ 硫酸溶液中において， 不働態化鋼の自活性化に伴い, 鋼電位は不働態域の電位 から活性態域の電位にまで卓方向に変化する。このとき の自己活性化に要する時間一自己活性化時間一を測定し て，不働態化鋼の耐食性を判定した。処理方法すなわち 化学的不働態化処理あるいは定電位不働態化処理にかか わらず，自己活性化時間は不働態化処理電位を貴方向に すると増大し，またその值が急激に変化する電位が認め られる。18-8ステンレス鋼および $\mathrm{Fe}, \mathrm{Cr}, \mathrm{Ni}$ の分極 曲線の比較から，この電位に近い $0.4 \mathrm{~V}$ なる臨界電位に おいて，不働態皮膜が結合水の多い $\mathrm{Cr}$ 酸化物型から $(\mathrm{Fe} \cdot \mathrm{Cr} \cdot \mathrm{Ni})$ 酸化物型に変化するものと推定された。 その変化に伴い耐食性が急変すると結論された。

同じようにエッチング電位も不働態化鋼の自己活性化 
時間を変化させる。最大の耐食性はー $0.32 \mathrm{~V}$ なる活性態 電位に扰いてエッチングしたときに得られた。純金属の 分極曲線はこの電位においてクロムが選択的に濃縮する ことを示している。

(昭和47年 1 月 27 日受理)

$$
\text { 文献 }
$$

1) N. Azzerri, L. Giuliani \& G. Bombara: Corrosion, 26, 381 (1970).

2) ステンレス鋼便覧， p. 770, 日刊工業新聞社 (1960).

3) 柴田俊夫, 岡本 剛: 北大工学部研究報告, 48, 165 (1965).

4) G. Okamoto \& T. Shibata: Corr. Sci., 10, 371 (1970).

5) 柴田俊夫, 岡本 剛, 斉藤功夫：電気化学協会 第35回大会講演要旨集, C108 (1968).

6) G. Okamoto \& T. Shibata: Proc. 3 rd Int.
Congr. Metallic Corrosion, Vol. 1, p. 396 , Moscow (1969).

7) Y. M. Kolotyrkin: Z Elektrochem, 62, 664 (1958).

8) N. Sato \& G. Okamato: J. Electrochem. Soc., 110, 605 (1963).

$9)$ U. F. Franck: Z. Naturforsch. 4a, 383 (1949).

10) V. V. Andreeva: Corrosion, 20, 35 t (1964).

11）工藤清勝, 佐藤教男：第17回剫食防食討論会講 演要旨集, p. 361 (1970).

12) J. Siejka, J. Yahalom \& C. Cherki : 3 rd Int. Conference on Passivity of Metals, Cambridge, England (1970).

13) K. N. Goswami \& R. W. Staehle: 3rd Int. Conference on Passivity of Metals, Cambridge, Engłand (1970). 